\title{
COMMENT
}

\section{LOST WILLS AND THE REGISTER OF WILLS}

\author{
JoHN E. WALSH, JR.†
}

The Pennsylvania Registers of Wills are elected officials, each of whom serves in one of the sixty-seven counties of the Commonwealth. Their duties are in large part defined by various acts of the legislature, principally the Fiduciaries Act of $1949,{ }^{1}$ the Register of Wills Act of $1951,{ }^{2}$ and the Orphans' Court Act of $1951 .^{3}$ In addition, some of their powers and areas of jurisdiction have been delineated by the Orphans' Courts of the various counties and rulings of the Supreme Court of Pennsylvania.

Both lawyers and the general public are inclined to believe that the Register is primarily an administrator. To a large extent this is true, but the Register is also vested with certain significant quasijudicial functions. The Pennsylvania Supreme Court has characterized the Register as a judge, whose decisions are judicial and therefore unimpeachable except by appeal. ${ }^{4}$ Under the Register of Wills Act of 1951, the Register exercises exclusive probate jurisdiction. ${ }^{5}$

Despite the kind judicial description of Registers as judges, neither my colleagues in the other sixty-six counties nor I really occupy such a position, because practically all of our quasi-judicial decisions can be appealed to the judges of the Orphans' Courts. However, we have grown jealous of the plenary authority given to us in probate matters. While the legislature has granted exclusive authority over questions of distribution to the Orphans' Courts, it clearly intended to vest probate jurisdiction in the Registers. ${ }^{6}$

Notwithstanding this division of functions, the Register does at times indirectly encounter distributional questions. This may occur

$\doteqdot$ Register of Wills, Philadelphia County, Pa. B.S. 1933, United States Naval Academy; LL.B. 1936, University of Pennsylvania. Member, Pennsylvania Bar. The author wishes to express his appreciation to David Jones, Esq., who assisted in the preparation of this Comment.

1 PA. Stat. Anv. tit. 20, $\$ 320.101-.1401$ (1950).

2 Pa. Stat. ANn. tit. 20, $\$ \$ 1840.101-.601$ (Supp. 1961).

3 Pa. Stat. ANn. tit. 20, $\$$ 2080.101-.801 (Supp. 1961).

4 Szmahl's Estate, 335 Pa. 89, 6 A.2d 267 (1939); West v. Young, 332 Pa. 248, 2 A.2d 745 (1938); Sehik's Estate, 300 Pa. 45, 150 Atl. 101 (1930); McNichol's Estate, $282 \mathrm{~Pa} .187,127$ Atl. 461 (1925).

5 Lennox v. Clark, $372 \mathrm{~Pa} .355,384,93$ A.2d 834, 847 (1953) (concurring opinion).

6 See Rockett Will, 348 Pa. 445, 35 A.2d 303 (1944); Carson's Estate, $241 \mathrm{~Pa}$. 117, 88 Atl. 311 (1913); Hegarty's Appeal, 75 Pa. 503 (1874). 
when he rules on the validity of a will offered for probate, probates a document other than the one originally offered, or finds that a decedent died intestate. This Article will discuss one such area-lost wills-in which the Register's quasi-judicial decision may have important distributional implications. I have selected this topic for two reasons. Experience in the conduct of my office has led me to believe that the implications and consequences of lost wills are not completely understood in Pennsylvania. In addition, I am of the opinion that this is an area in which the Register should be allowed greater discretion than the appellate courts presently permit.

A will is considered lost whenever something other than the original document is offered for probate. ${ }^{7}$ Of course no substitute form of evidence rises to the status of an original will. Quantitative and qualitative evidence establishing the execution and contents of the original, a scrivener's notes or draft, ${ }^{8}$ even a copy signed by the decedent ${ }^{9}$ will not take its place. Under Pennsylvania law, it is most difficult to prove a lost will. ${ }^{10}$ Generally speaking, this is desirable to discourage and minimize the danger of fraudulent behavior on the part of fiduciaries, beneficiaries, legatees, and other interested parties. However, in certain circumstances the burden of proving a lost will should and could be eased without serious harm. The present rules occasionally favor perpetrators of fraud at the expense of testators and legitimate beneficiaries. They also deprive the Register of Wills of the right, which may be tantamount to a duty, to prevent fraudulent frustration of a testator's intent.

Although the Pennsylvania Orphans' Courts and appellate tribunals have never explicitly authorized the Register to "sit in the testator's chair" when considering probate matters, this is what he must do in deciding whether to probate a lost will. Therefore, when the testator's chair is pulled from under him by loss or tortious destruction of the original will, the Register should have the power to bring the matter to a just conclusion.

\section{Loss or Destruction of the Original WiLl}

Whenever a will is placed beyond the reach of the will searcher, whether by the decedent himself, a third party, or natural forces, it is considered lost.

7 See Smith \& Aker, Will Drafting in Pennsylvania \$1.10A (1958).

8 See Weber's Estate, 268 Pa. 7, 110 Atl. 785 (1920).

9 Bates' Estate, $286 \mathrm{~Pa} .583,134$ Atl. 513 (1926) ; cf. Murray Will, $404 \mathrm{~Pa} .120$, 171 A.2d 171 (1961); Gardner's Estate, 164 Pa. 420, 30 Atl. 300 (1894).

10 See SMIth \& AKer, op. cit. supra note 7, \$1.10. See generally 40 PennsyLvania Law Encyclopedia Wills $\$ \$ 194,202,215$ (1961). 
The testator himself may misplace his will through carelessness, forgetfulness, or neglect. He may also accidentally destroy it. In both of these instances, the will is considered lost, regardless of whether the decedent knew that the document was missing or destroyed, if he failed to execute another. ${ }^{11}$

The carelessness of the decedent's attorney or depository may cause the loss of a will. Because it is difficult to prove who had possession of the document immediately prior to the decedent's death, direct responsibility for loss often cannot be placed on these parties. But the reported cases do suggest that in many instances greater care on their part might have avoided the problem. ${ }^{12}$

Occasionally, a will is fraudulently destroyed or suppressed by third persons. Often, such persons would be adversely affected by probate of the original document. Such fraudulent conduct may be proved by circumstantial evidence ${ }^{13}$ or admission. ${ }^{14}$

There has been no Pennsylvania appellate decision involving a will lost as the result of natural causes. One reported instance of a factually analogous situation, ${ }^{15}$ however, suggests the possibility of such an occurrence.

\section{Admission of a Lost Will to Probate}

The Pennsylvania courts have held that, under certain circumstances, the Register of Wills may admit a lost will to probate. Traditionally, four elements of proof had to be established before such action could be taken: (1) that the original will was lost or had otherwise disappeared; (2) that the original had been properly executed; (3) the contents of the lost will; (4) an explanation for the non-production of the original document. ${ }^{16}$ In recent formulations, the courts, without explanation, have deleted the first requirement from the list of necessary elements of proof. ${ }^{17}$ This may be attributable to a joinder of that re-

11 See Weber's Estate, 268 Pa. 7, 110 Atl. 785 (1920); Estate of Deaves, 140 Pa. 242, 21 Atl. 395 (1891); Almeida's Estate, 21 Pa. Dist. 161 (Orphans' Ct. Phila. County 1911).

12 See, e.g., Tribit Estate, 81 Pa. D. \& C. 29 (Orphans'. Ct. Delaware County 1952) ; Pare's Estate, 15 Pa. Dist. 553 (Orphans' Ct. Allegheny County 1906).

13 Gardner's Estate, 164 Pa. 420, 30 Atl. 300 (1894).

14 Gfeller v. Lappe, $208 \mathrm{~Pa}$. 48, 57 Atl. 59 (1904) (testimony as to admission made out of court).

15 Trevaskis' Estate, 345 Pa. 525, 29 A.2d 29 (1942) (will made contingent upon loss cf prior will in flood denied probate when prior will was found).

16 Foster's Appeal, $87 \mathrm{~Pa} .67$ (1878).

17 See Murray Will, 404 Pa. 120, 171 A.2d 171 (1961). In Michell v. Low, $213 \mathrm{~Pa}$. 526, 63 Atl. 246 (1906), the court stated: "To justify the verdict, the jury was required to find, on sufficient evilence, (1) the due execution of the alleged will by the testator; (2) its contents substantially as set forth in the copy attached to the precept as exhibit "A," and (3) that the instrument was unrevoked at the death of the testator." Id. at 529, 63 Atl. at 247. 
quirement with the necessary explanation of non-production, since both may be proved by the same evidence. In many recent lost will cases, the problems of proof have been somewhat alleviated by the existence of carbon copies.

\section{A. Proof of Execution}

Execution of a lost will must be established in essentially the same manner as an original. The necessary formalities are apparently those prescribed by the Wills Act in effect at the time of proposed probate. ${ }^{18}$ If proof of execution is insufficient, probate must be denied, even though the other required elements of proof are satisfied. ${ }^{19}$

The testimony of two witnesses is necessary to prove that a decedent signed a lost will. The signature of an original will may be verified by any two persons able to identify it, even though they were not present at the time of execution. In probating a lost will, however, the Register must be satisfied that the two witnesses actually observed the testator sign the original of the will which is offered. ${ }^{20}$ There is no binding requirement that the same witnesses also be called to testify about the contents of the will, but courts generally prefer such testimony, particularly when the decedent had shown them the will or discussed its contents with them. ${ }^{21}$

Qualitative as well as quantitative requirements of proof are imposed. The witnesses' testimony must be adequate without the support of circumstantial evidence. In the early case of Hock $v$. Hock, ${ }^{22}$ the Pennsylvania Supreme Court held:

Proof of execution must be made by two witnesses, each of whom must separately depose to all facts necessary to complete the chain of evidence, so that no link in it may depend on the credibility of but one. Where the evidence is positive, there can be no difficulty, for the witnesses then attest the simple fact of execution itself; but where the evidence of one, or both, is circumstantial, each must make proof complete in itself; so that, if the act of assembly were out of the question, the case would be well made out, by the evidence of either. ${ }^{23}$

18 See, e.g., Harrison's Estate, $316 \mathrm{~Pa}$ 15, 173 Atl. 407 (1934) ; Michell v. Low, supra note 17; Randal's Estate, 5 i Montg. Co. Law Rptr. 126 (Orphans' Ct. Montgomery County, Pa., 1935) ; cf. Hock v. Hock, 6 S. \& R. 47 (Pa. 1820).

10 Harrison's Estate, supra note 18; McKenna v. McMichael, $189 \mathrm{~Pa} .400,42$ Atl. 14 (1899).

20 Harrison's Estate, supra note 18 (dictum). In the Harrison case, probate was denied when one subscribing witness predeceased the testator, and the other could not remember having witnessed the execution of the "will." In Randal's Estate, 51 Montg. Co. Law Rptr. 126 (Orphans' Ct. Montgomery County, Pa., 1935), it was alleged that the decedent executed the will by mark. Probate was refused because the witnesses could not establish that the mark had been made in their presence.

21 See Hock v. Hock, 6 S. \& R. 47 (Pa. 1820).

22 Ibid.

23 Id. at 47. 
More recently, the court stated that "a lost will should not be capable of proof in a way that one produced could not be proven. Circumstances cannot take the place of the second witness to a will which is produced." 24

\section{B. Proof of Contents}

After execution of a purportedly lost will has been established, the contents of the instrument must be proved. ${ }^{25}$ Again, two witnesses are required, ${ }^{28}$ but beyond the requirement of "substantial proof," 27 there has been no definitive judicial statement of the criteria to be applied in evaluating the evidence offered. It must, however, be clearly established that the instrument about which the witness is testifying is the one that is being offered for probate. ${ }^{28}$ A failure to make this vital connection will defeat the proponent's cause.

\section{Explanation of Non-production of the Original}

The proponent of a lost will must also explain why the original is not offered for probate. A decedent who had possession of the document immediately prior to death is presumed to have caused its disappearance in animo revocandi. ${ }^{29}$ This presumption also applies if the decedent had access to the will just before he died, even though he did not have possession. ${ }^{30}$ Access to the document need not be conclusively established; it is sufficient if circumstances make it likely that he had possession or access. ${ }^{31}$

The proponent of a lost will has the burden of rebutting the presumption of revocation. If he fails to do so, probate must be denied. The presumption of revocation may be rebutted by negative evidence. It may be shown that the decedent did not have possession of his will prior to death, ${ }^{32}$ or that if he did, he lacked the physical power to destroy

24 Harrison's Estate, 316 Pa. 15, 17-18, 173 Atl. 407, 408 (1934).

25 "[T] here must be proof ... of the contents, substantially as set forth in the copy ... ." Lawman's Estate, $272 \mathrm{~Pa} .237,239,116$ Atl. 538, 539, cert. denied sub nom. Lawman v. People's Sav. \& Trust Co., 259 U.S. 583 (1922) ; Hodgson's Estate, $270 \mathrm{~Pa}$. 210, 112 Atl. 778 (1921); Michell v. Low, $213 \mathrm{~Pa}$. 526, 63 Atl. 246 (1906). (1906).

26 Lawman's Estate, supra note 25; Fallon's Estate, 214 Pa. 584, 63 Atl. 889

27 See note 25 supra.

28 In Hodgson's Estate, $270 \mathrm{~Pa}$. 210, 112 Atl. 778 (1921), probate was denied when one of the witncsses could not establish that the instrument which he saw executed was the one offered for probate.

29 Bate's Estate, 286 Pa. 583, 134 Atl. 513 (1926).

30 Stewart's Estate, $149 \mathrm{~Pa} .111,24$ Atl. 174 (1892).

31 Tribit Estate, 81 Pa. D. \& C. 29 (Orphans' Ct. Delaware County 1952).

32 Bregy, Pexnsylvania Intestate, Wills and Estates Acts of 1947, at 2313 (1949). In O'Neill's Estate, 58 Pa. D. \& C. 351 (Orphans' Ct. Bucks County 1946), the court stated that the presumption did not even arise in such a case. 
his will..$^{33}$ Also, the decedent may have indicated, immediately prior to death, that he believed that his will was still in existence. ${ }^{34}$ Positive evidence, of course, can also be introduced. The decedent' $s$ character, condition, acts, and declarations are relevant to the question of whether the decedent destroyed the will himself. ${ }^{35}$ Someone other than the decedent may have tampered with the instrument. Circumstantial evidence ${ }^{36}$ or an admission ${ }^{37}$ may show that interested parties fraudulently suppressed the will. Courts will not, however, presume fraudulent destruction $;^{38}$ on the contrary, the innocence of third persons is assumed. ${ }^{30}$

Courts have had difficulty determining what evidence is admissible to rebut the presumption of revocation. The most troublesome issues have been the legitimacy of considering the decedent's intent, declarations, knowledge of loss, and other surrounding circumstances. Declarations by the decedent affirming his belief in the existence of his will are relevant. ${ }^{40}$ Similarly, evidence that the testator was aware of loss or destruction will be admitted to defeat the explanation of non-production. ${ }^{41}$ The courts have not, however, squarely determined whether evidence of the decedent's intent to make a new will is admissible. Such a declaration of intent would seem to be relevant, as it would weaken the presumption of revocation. ${ }^{42}$

The required explanation of non-production is not satisfied, however, by a mere rebuttal of the presumption of revocation. If the decedent knew that his will was lost or destroyed, but failed to execute a new one, probate must still be denied. ${ }^{48}$

Evidence of surrounding circumstances may be relevant both to non-production and the presumption of revocation. It may establish that the decedent was too weak or ill to have destroyed his will, ${ }^{44}$ or that he was a man of such character, tenacity, or deliberateness that he

33 Glockner v. Glockner, 263 Pa. 393, 106 Atl. 731 (1919).

34 Ibid.; Foster's Appeal, 87 Pa. 67 (1878).

35 Gardner v. Gardner, 177 Pa. 218, 35 Atl. 558 (1896) ; Gardner's Estate, 164

$\mathrm{Pd} .420,30$ Atl. 300 (1894); Stephenson's Estate, $6 \mathrm{~Pa}$. County Ct. 628 (1888).

36 Gardner v. Gardner, supra note 35; Gardner's Estate, supra note 35.

37 Gfeller v. Lappe, $208 \mathrm{~Pa} .48,57$ Atl. 59 (1904) (testimony as to admission made out of court).

38 Stewart's Estate, 149 Pa. 111, 24 Atl. 174 (1892).

39 Michell v. Low, $213 \mathrm{~Pa}$. 526, 63 Atl. 246 (1906).

40 Glockner v. Glockner, 263 Pa. 393, 106 Atl. 731 (1919).

41 Weber's Estate, $268 \mathrm{~Pa} .7,110$ Atl. 785 (1920); Estate of Deaves, $140 \mathrm{~Pa}$. 242, 21 Atl. 395 (1891); Almeida's Estate, 21 Pa. Dist. 161 (Orphans' Ct. Phila. County 1911).

42 The problem has been alluded to but not discussed at length. See Weber's

Estate, supra note 41 ; Almeida's Estate, supra note 41 .

43 Cases cited note 41 supra.

44 See note 33 supra and accompanying text. 
was unlikely to destroy the document. ${ }^{45}$ On the other hand, such evidence might strengthen the presumption of revocation by affirmatively proving that the decedent had possession of the will prior to death. ${ }^{48}$

Circumstantial evidence relating to the conduct of third persons, however, is not liberally admitted by courts. As indicated earlier, third parties are assumed to be innocent of fraud. ${ }^{47}$ Proof of fraud, therefore, must be convincing ${ }^{43}$ to rebut the presumption of revocation, ${ }^{49}$ and lay the foundation for a finding that the will was duly executed and is entitled to probate. ${ }^{50}$

\section{Why Prove A Lost Will?}

The primary purpose of proving a lost will is to determine the the decedent's distributive intent. ${ }^{51}$ An incidental motive is the avoidance of intestacy. ${ }^{52}$ Also, a lost will may have revoked another will offered for probate. Revocation by a lost instrument, however, is severely limited by certain doctrines peculiar to that problem. It is hornbook law in Pennsylvania that a will cannot be revoked by parol. Proof of a lost revoking instrument, therefore, is not usually permitted ${ }^{53}$ except when fraud is alleged. ${ }^{54}$ It is also held that an original document, which was itself revoked, may revoke a previous will, ${ }^{55}$ but that a copy of the revoking document is insufficient for that purpose. ${ }^{56}$

Finally, the republication of a lost will by codicil does not obviate the necessity of proving the original will, although the codicil itself may be separately probated. ${ }^{57}$ Lost codicils themselves are subject to the same requirements of proof as lost wills. ${ }^{58}$

\section{Critique of Existing Law}

Several inequities in the present law of lost wills obstruct the Register's search for just results.

45 See Gardner v. Gardner, 177 Pa. 218, 35 Atl. 558 (1896) ; Gardner's Estate, $164 \mathrm{~Pa} .420,30$ Atl. 300 (1894).

46 Tribit Estate, 81 Pa. D. \& C. 29 (Orphans' Ct. Delaware County 1952).

47 See note 39 supra and accompanying text.

48 Stewart's Estate, 149 Pa. 111, 24 Atl. 174 (1892).

49 See cases cited note 45 supra.

50 Buchle's Estate, $3 \mathrm{~Pa}$. Dist. 16 (Orphans' Ct. Phila. County 1893).

51 See, e.g., Fallon's Estate, 214 Pa. 584, 63 Atl. 889 (1906).

52 Cf. Ford's Estate, 301 Pa. 183, 151 Atl. 789 (1930).

53 Shetter's Estate, $303 \mathrm{~Pa} .193,154$ Atl. 288 (1931).

54 See Koehler's Estate, 316 Pa. 321, 175 Atl. 424 (1934) (dictum).

55 Ford's Estate, 301 Pa. 183, 151 Atl. 789 (1930).

56 Harrison's Estate, 316 Pa. 15, 173 Atl. 407 (1934).

57 See O'Neill's Estate, 58 Pa. D. \& C. 351 (Orphans' Ct. Bucks County 1946).

58 See Stewart's Estate, 149 Pa. 111, 24 Atl. 174 (1892). 
The "two witnesses" rule for execution occasionally produces undesirable results. Although only one subscribing witness sirvives the decedent, circumstantial evidence may convincingly support th, e conclusion that the lost will was validly executed. The courts could easily retreat from this rule; the earliest authority for the rule is Hock v. $H o c k,{ }^{50}$ a case which did not even involve a lost will.

It would admittedly be difficult to formulate a truly definitive standard for the quality of proof necessary to prove the contents of a lost will, but the present "substantiality" test ${ }^{60}$ is much too vague. Also, the courts have neglected to determine the method by which witnesses are to identify the will as to the contents of which they are testifying. It is presently unsettled whether they may refer to a copy, to a scrivener's notes, or must testify without refreshing their memories.

The presumption of revocation is sound. The courts, however, have not determined how much evidence is necessary to rebut. Nor have they decided the relative weight to be given various elements of proof, such as declarations by the decedent and his opportunity to destroy the original.

Under present law, an original will, which was itself revoked, may nevertheless revoke an earlier document. A lost will, however, may not be probated so as to do likewise. This is not only inconsistent, but also unfortunate, for the refusal to probate may frustrate the decedent's distributional intent.

Once a lost will has been established, the question arises of exactly what is to be probated. There are several possibilities, including a copy of the original, a scrivener's notes, excerpts from the record, and the testimony of witnesses before the Register. The courts, however, have not yet chosen from this list.

\section{RECOMMENDATIONS}

Because the present law of lost wills is excessively rigid, just causes are often dismissed for inability to meet its demands. There is, therefore, a need for a new statement of positive but flexible guiding principles. This is not to say that the present requirements of proof are unacceptable as guidelines; but they should not be permitted to become so inflexible as to exclude meritorious cases. The Register of

696 S. \& R. 47 (Pa. 1820).

60 See note 27 supra. 
Wills should have the power to waive or modify one or more requirements where the need for doing so is indicated by the circumstances of a particular case. He should have the discretionary right to balance the safeguards which the present rules provide against the risk of an unjust result. In order to avoid a harsh outcome, the Register should be able to consider every element that enters into the contest, including the adversity of the parties, the availability of subscribing witnesses, and circumstantial evidence. This would mitigate the inequities of the "two witnesses" rule and the presumption of revocation. If, on all the evidence, the Register is convinced that the lost will has been satisfactorily established, he should not be prohibited from granting probate for the lack of one subscribing witness.

More specifically, in dealing with lost wills, less reliance should be placed on statutory requirements for the proof of wills. The current legislation, drafted with reference to original documents, cannot be expected to suit all the exigencies of lost will situations. Strict adherence to statutory standards in an area which necessarily involves the evaluation of circumstances and non-specific factual considerations deprives the subject of the flexible treatment that it deserves.

The quality of proof required to establish the contents of a lost will might continue to be measured by the "substantiality" test. That standard, however, should be more definitively formulated. The requirement of verbatim recital of contents should be dropped. Instead, witnesses should be required to present the decedent's general testamentary scheme, testify as to unusual dispositions, and describe the forms of disposition. In doing so, interested persons should not be permitted to refer to any notes; others, such as a scrivener, might refer to a copy or other secondary sources.

In the absence of positive evidence of revocation, the presumption should be deemed rebutted on presentation of any credible evidence to the contrary. When the presumption is supported by positive evidence, however, substantial evidence should be required for rebuttal. The Register should be designated as the proper person to judge credibility and substantiality.

If a copy is available, it should be used for probate. In the absence of a copy, excerpts from the Register's record should be probated. A copy insures accuracy, while the transcript guarantees truth.

Of course, the most satisfactory approach to the lost will problem is prevention. Attorneys and scriveners should warn their clients to preserve their wills in safe and accessible places and apprise prospective testators of the often dire consequences of losing a will. 